\title{
Artificial ponds in Central Europe do not fall behind the natural ponds in terms of macrophyte diversity
}

\author{
Kateřina Bubíková ${ }^{1,2,{ }^{*}}$ and Richard Hrivnák ${ }^{1}$ \\ ${ }^{1}$ Institute of Botany, Plant Science and Biodiversity Centre, Slovak Academy of Sciences, Dúbravská cesta 9, SK-845 23 Bratislava, \\ Slovak Republic \\ ${ }^{2}$ Water Research Institute, Nábrežie arm. gen. L. Svobodu 7, SK-812 49 Bratislava, Slovak Republic
}

\begin{abstract}
We studied macrophyte composition and 24 environmental variables in 69 ponds of both natural and artificial origin in Slovakia. We tested differences in $\alpha$ and $\gamma$ diversity and $\beta$ similarity between natural and artificial ponds for helophytes, hydrophytes, red list species and all species. We also assessed effects of environmental variables on species richness of studied ponds by generalised linear models (GLM). For local diversity, the significant difference was obtained only in case of helophytes. Beta similarity significantly differed for all the species groups. Total species numbers (gamma diversity) of all the groups were higher in natural ponds with the exception of hydrophytes. A randomization test of $\gamma$ diversity yielded significant differences for helophytes and all species groups; richness and diversity of hydrophytes and red list species were not significantly different. Thus, we can conclude that even though natural ponds have a significantly higher regional diversity, local diversity is comparable not only for common species but also endangered red-listed macrophytes and thus artificial ponds could serve as proper secondary habitats for macrophytes. GLM showed different effect of environmental predictors on richness of studied species and pond groups and a slightly higher explained variability in natural (40\%) compared to artificial (37\%) ponds.
\end{abstract}

Keywords: comparative diversity / lentic habitats / aquatic plants / species richness

Résumé - Les mares artificielles d'Europe centrale ne sont pas en retard par rapport aux mares naturelles en termes de diversité des macrophytes. Nous avons étudié la composition des macrophytes et 24 variables environnementales dans 69 mares d'origine naturelle et artificielle en Slovaquie. Nous avons testé les différences de diversité $a$ et $g$ et de similitude $b$ entre les mares naturelles et artificielles pour les hélophytes, les hydrophytes, les espèces de la liste rouge et toutes les espèces. Nous avons également évalué les effets des variables environnementales sur la richesse en espèces des mares étudiées à l'aide de modèles linéaires généralisés (GLM). En ce qui concerne la diversité locale, une différence significative n'a été obtenue que dans le cas des hélophytes. La similarité bêta était significativement différente pour tous les groupes d'espèces. Le nombre total d'espèces (diversité gamma) de tous les groupes était plus élevé dans les mares naturelles, à l'exception des hydrophytes. Un test de randomisation de la diversité g a produit des différences significatives pour les hélophytes et tous les groupes d'espèces; la richesse et la diversité des hydrophytes et des espèces de la liste rouge n'étaient pas significativement différentes. Par conséquent, nous pouvons conclure que même si les mares naturelles présentent une diversité régionale nettement plus grande, la diversité locale est comparable non seulement pour les espèces communes, mais aussi pour les macrophytes inscrits sur la liste rouge, ce qui fait que les mares artificielles pourraient servir d'habitats secondaires appropriés pour les macrophytes. Les modèles linéaires généralisés ont montré différents effets des variables environnementales prédictrices de la richesse des espèces et des groupements de mares étudiées et une variabilité naturelle (40\%) légèrement plus élevée que celle des mares artificielles (37\%).

Mots-clés : diversité comparative / habitats lentiques / plantes aquatiques / richesse spécifique

\footnotetext{
*Corresponding author: katka.bubikova@gmail.com
} 


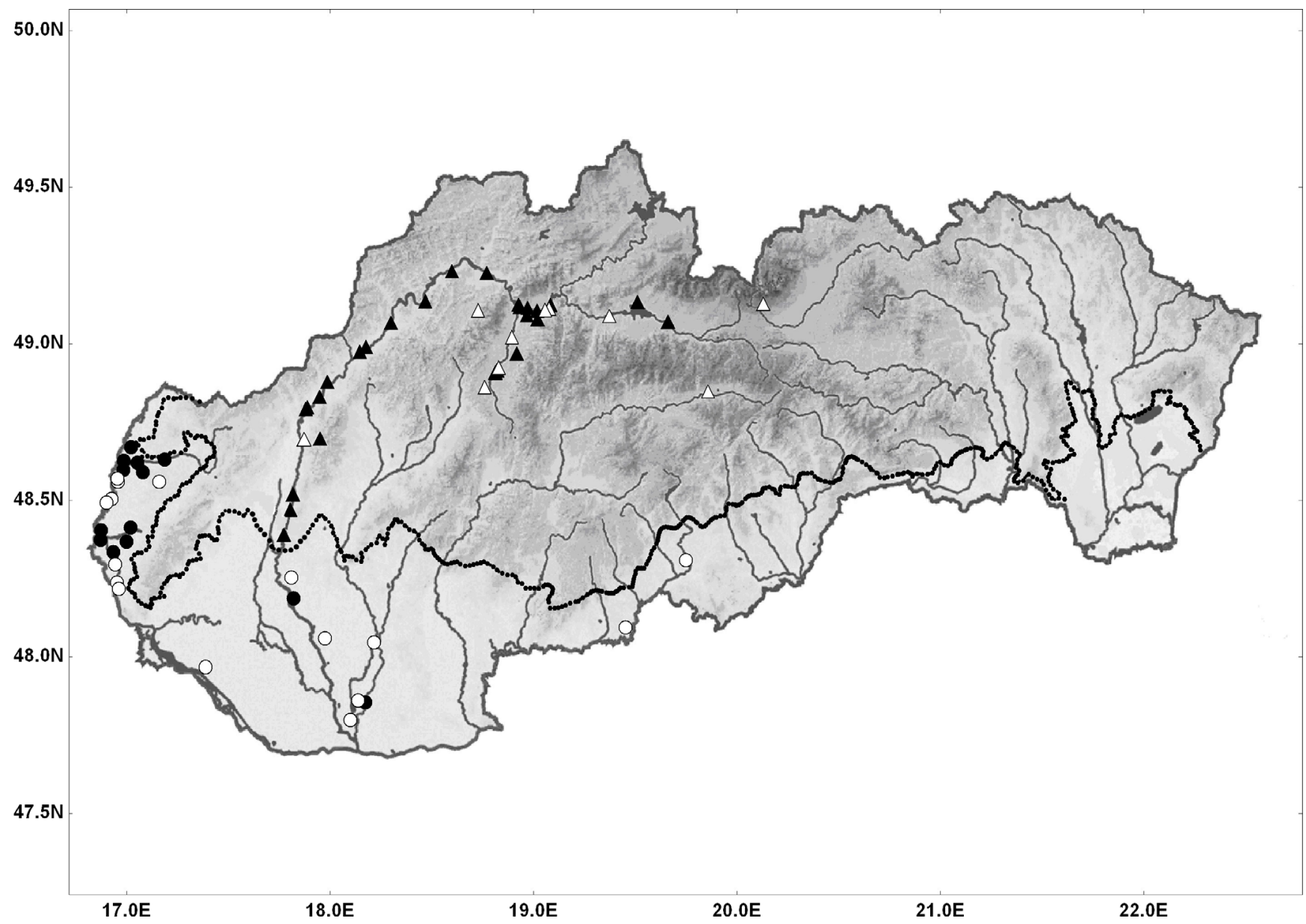

Fig. 1. Location of studied localities in Slovakia. Circles and triangles represent localities in Pannonian and Carpathian region, respectively; empty symbols indicate waterbodies with natural origin, solid artificial ponds. Dotted line represent border between bioregions.

\section{Introduction}

Intensive limnological research during recent decades has brought several studies which state that ponds play an irreplaceable role in maintaining macrophyte diversity in landscape (Oertli et al., 2002; Biggs et al., 2005; 2017; Céréghino et al., 2014). Together with the facts that ponds have a greater total area than lakes on a global scale (Downing et al., 2006), and a smaller catchment area in comparison with other aquatic ecosystems such as rivers (Davies et al., 2008b), small standing inland waters encourage for their protection. Smaller catchments are less exposed to the harmful effects of human activities such as use of fertilisers or waste discharge, and more isolated smaller waterbodies enhance aquatic diversity heterogeneity and species composition (Akasaka and Takamura, 2012; Waldon, 2012). Such information is very useful in the case of nature protection. Generally, freshwaters belong to the most threatened ecosystems worldwide due to climate change, direct destruction by man or natural succession changes (Millennium Ecosystem Assessment, 2005; Dudgeon et al., 2006). Along with freshwaters decline aquatic macrophytes are also vanishing. In addition to natural ponds, scientific attention has recently focused also on artificial ponds as potentially biodiversity valuable habitats
(Chester and Robson, 2013). Due to diverse range of environmental conditions in artificial waterbodies, it is probably impossible to unambiguously confirm the importance of such ponds for maintaining aquatic macrophyte diversity without taking into account the waterbody specifics. Some kinds of human influences and local management, such as bankside angling, biomass removal or extensive fish farming are beneficial for macrophytes (Linton and Goulder, 2000; Broyer and Curtet, 2012; Sumberová et al., 2012) because they limit successional changes (Dodds and Whiles, 2010; Sayer et al., 2012). On the other hand, some harmful consequences are linked to management practices such as dense fish stocks and manipulation of water regimes, or indirect influences resulting from intensive agriculture leading to the eutrophication of water (Crivelli, 1983; Scheffer and Carpenter, 2003; Declerck et al., 2006; Akasaka et al., 2010; Kadoya et al., 2011). Moreover, stabilisation of banks in waterbodies causes a loss of littoral ecotones with a negative impact on macrophyte occurrence in ponds (Kadoya et al., 2008, 2011; Zelnik et al., 2012).

Despite the fact that several studies have pointed out that artificial ponds are suitable refuges for macrophytes (Gee et al., 1997; Spałek, 2006; Chester and Robson, 2013), critical assessments of their real contribution to species diversity at local, among-site or regional levels have so far been 
Table 1. Summary characteristics of environmental variables. Mean values with range (in the brackets) are displayed. Asterisks in the column "M-W test" indicate significant result of Mann-Whitney $U$ test for comparison of variables $\left({ }^{*} p<0.05,{ }^{* *} p<0.01,{ }^{* * *} p<0.001, n s=\right.$ nonsignificant difference, $x=$ categorical variable). Mann-Whitney $U$ test was not applied for categorical variables banks, bioregion and connectivity variables.

\begin{tabular}{|c|c|c|c|}
\hline Variable characteristics & Artificial $(n=43)$ & Natural $(n=26)$ & $\mathrm{M}-\mathrm{W}$ test \\
\hline Altitude (m a.s.l.) & $200(110-594)$ & $163(108-1219)$ & ns \\
\hline Gradual or Steep bank & . & . & $\times$ \\
\hline Carpathian or Pannonian & . & . & $\times$ \\
\hline Type of connectivity $(1=$ main channel to 3 separated pond $)$ & $3(2-3)$ & $3(2-3)$ & $\times$ \\
\hline Cover of man-made structures in 100 metres from the sampling site (\%) & $5(0-95)$ & $0(0-45)$ & $* *$ \\
\hline Cover of fields in 100 metres from the sampling site $(\%)$ & $0(0-95)$ & $0(0-70)$ & ns \\
\hline Cover of forests in 100 metres from the sampling site (\%) & $30(0-100)$ & $35(4-100)$ & ns \\
\hline Cover of meadows in 100 metres from the sampling site (\%) & $10(0-90)$ & $20(0-95)$ & ns \\
\hline Cover of wetlands in 100 metres from the sampling site (\%) & $0(0-99.5)$ & $15(0-70)$ & ns \\
\hline Content of water ammonia & $0.07(0-3.11)$ & $0.31(0-4.34)$ & $*$ \\
\hline Content of water nitrite & $0.05(0-0.43)$ & $0.03(0-0.42)$ & ns \\
\hline Content of water nitrate & $0.65(0.02-8.3)$ & $0.62(0-5.43)$ & ns \\
\hline Content of water phosphates & $0.08(0-1.08)$ & $0.13(0-2.75)$ & ns \\
\hline Shading by woody vegetation (higher than 3 metres) on banks (\%) & $60(0-100)$ & $92.5(0-100)$ & $* *$ \\
\hline Cover of coarse substrate on the bottom (\%, cf. Janauer 2003) & $0(0-60)$ & $0(0-10)$ & $\mathrm{ns}$ \\
\hline Cover of fine substrate on the bottom (\%, cf. Janauer 2003) & $10(0-100)$ & $100(10-100)$ & $* * *$ \\
\hline Cover of gravel on the bottom (\%, cf. Janauer 2003) & $2(0-100)$ & $0(0)$ & $* * *$ \\
\hline Cover of sand on the bottom (\%, cf. Janauer 2003) & $0(0-30)$ & $0(0)$ & $* *$ \\
\hline Water conductivity $(\mu \mathrm{S} . \mathrm{cm}-1)$ & $464.3(63.5-1445)$ & $516.1(20.3-1986.5)$ & ns \\
\hline Average water depth $(\mathrm{cm})$ & $140(22-300)$ & $64.4(19-145.8)$ & $* * *$ \\
\hline Water reaction & $8.1(6.91-9.44)$ & $7.525(5.61-8.9)$ & $* *$ \\
\hline Type of water regime ( $1=$ permanently waterlogged to $4=$ dried every year) & $1(1-2)$ & $2(1-3)$ & $\times$ \\
\hline Water temperature $\left({ }^{\circ} \mathrm{C}\right)$ & $20.1(13.9-28.8)$ & $19.6(14-26.4)$ & ns \\
\hline Turbidity of water $(1=$ clear to $4=$ turbid $)$ & $2(1-4)$ & $2(1-4)$ & $\mathrm{ns}$ \\
\hline
\end{tabular}

unsatisfactory. None of these studies directly compared diversity between natural and artificial ponds, with authors stating that artificial ponds are suitable refuges for both common and endangered macrophytes and that they are species rich. Moreover, there is a large number of studies exploring how environmental factors shape species composition or diversity both in natural (Toivonen and Huttunen, 1995; Della et al., 2008; Lukács et al., 2015) and artificial ponds (Edvardsen and Økland, 2006; Broyer and Curtet, 2012; Wezel et al., 2014), but comparisons of factors among ponds with different origins are relatively few.

The aims of our study were to: (i) characterise environmental conditions and diversity of macrophytes in the studied artificial and natural ponds and test whether there are any differences between artificial and natural lentic waterbodies, and (ii) to identify how environmental factors shape species diversity in ponds with different origins.

\section{Methods}

\subsection{Study area and data sampling}

The study was carried out in two Central European bioregions - the Pannonian and the Western Carpathian (hereafter as the Carpathian; European Commission, 2014) which provide heterogeneous landscape mosaics as well as a wide range of ecological gradients. We selected small ponds (standing waters with area in the range 0.05-2 ha, $c f$. Biggs et al., 2005) of both artificial and natural origin in Slovakia (Fig. 1). Artificial ponds as man-made aquatic habitats were represented by flooded gravel pits, mud pits and fishponds. Natural ponds within our study comprised oxbows ponds and flooded terrain depressions. Altogether, 69 ponds were inspected, 43 were artificial and 26 were ponds of natural origin. In each pond, all macrophyte species (including bryophytes, vascular plants and macroscopic algae from Charales order) were recorded. Macrophyte survey was performed by wading or from a boat using a rake within one randomly selected isosceles triangle-shaped sampling area of $100 \mathrm{~m}^{2}$ with the base following the pond margin and apex in the middle of the pond (Williams et al., 2004). Physicochemical, hydrological and landscape variables (Tab. 1) were collected in each pond. Water conductivity, $\mathrm{pH}$ and temperature were measured directly in the field by the portable CyberScan PC 650 device. Altitude was recorded by a Garmin GPS device. Water samples $(100 \mathrm{ml})$ were taken from three randomly selected locations at each sampling site. Samples were homogenized and frozen for further laboratory analysis of ammonium nitrogen $\left(\mathrm{NH}_{4}{ }^{+}\right)$, nitrate nitrogen $\left(\mathrm{NO}_{3}{ }^{-}\right)$, nitrite nitrogen $\left(\mathrm{NO}_{2}{ }^{-}\right)$and orthophosphate content $\left(\mathrm{PO}_{4}{ }^{3-}\right)$ (cf. Hrivnák et al., 2013). To reduce seasonality, all these measurements as well as water sampling were performed 
Table 2. Summary table of species diversity and results of tests of potential differences between artificial and natural ponds. Local diversity is presented by mean numbers of species at one locality and by results of permutational ANOVA used for testing of differences between artificial and natural ponds. Beta similarity is presented by mean Jaccard's index, differences were tested with test of multivariate homogeneity of variances ten times with randomly selected subsets due to uneven samples, $p$-values are represented. Gamma diversity shows total species numbers per species groups with $p$-values obtained in randomization test. Asterisks indicate statistically significant results, for details about tests see data analysis part in methods section.

\begin{tabular}{|c|c|c|c|c|c|c|}
\hline \multirow[t]{2}{*}{ Diversity/similarity } & \multirow[t]{2}{*}{ Species group } & \multirow[t]{2}{*}{ Artificial $(n=43)$} & \multirow[t]{2}{*}{ Natural $(n=26)$} & \multicolumn{3}{|c|}{ Tests results } \\
\hline & & & & p-value & R Sum Sq & Mean Sq \\
\hline \multirow{4}{*}{ Local (alpha) diversity } & All species & 3.2 & 5 & 0.98 & 0.00 & 0.0042 \\
\hline & Helophytes & 0.7 & 1.8 & $0.04 *$ & 17.025 & 17.0247 \\
\hline & Hydrophytes & 2.5 & 3.2 & 0.14 & 8.38 & 8.3796 \\
\hline & Red list species & 0.7 & 1 & 0.25 & 1.336 & 1.33573 \\
\hline & & & & p-value & & \\
\hline \multirow{5}{*}{ Among-site (beta) similarity } & All species & 0.125 & 0.069 & $0.023-0.001 *$ & & \\
\hline & Helophytes & 0.046 & 0.022 & $0.001^{*}$ & & \\
\hline & Hydrophytes & 0.150 & 0.097 & $0.848-0.001^{*}$ & & \\
\hline & Red list species & 0.042 & 0.027 & $0.005-0.001 *$ & & \\
\hline & & & & p-value & & \\
\hline \multirow{4}{*}{ Regional (gamma) diversity } & All species & 39 & 51 & $0.005^{*}$ & & \\
\hline & Helophytes & 12 & 24 & $0.001 *$ & & \\
\hline & Hydrophytes & 27 & 27 & 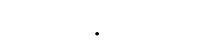 & & \\
\hline & Red list species & 11 & 13 & 0.105 & & \\
\hline
\end{tabular}

during vegetation sampling in the summer, repeated in the end of the summer (during September and early October) and mean values of two measurements were used for analysis. Average water depth was calculated from the measurements at 10 randomly selected locations within the sampling site. Percentage cover of five categories of land use (LU), (1) forests and bushes, (2) wetlands, (3) pastures, meadows and orchards, (4) agricultural fields and (5) built-up area was estimated within $100 \mathrm{~m}$ from the ponds. Shading of woody vegetation was estimated as percent cover of shrubs and trees on the banks higher than $3 \mathrm{~m}$. Percentage cover of fine, sand, gravel and coarse bottom substrate was estimated (Janauer, 2003). Type of water regime was estimated on the scale from 1 to $4(1=$ permanently waterlogged, $4=$ dried every year $)$ based on our repeated visits of the studied ponds during several years. Bank slope was visually estimated as gradual or steep with threshold $20^{\circ}$.

Nomenclature of plant species is in accordance with the checklist of Marhold and Hindák (1998), and the category of threat with the actual Slovak Red lists (Hindák and Hindáková, 2001; Eliáš et al., 2015).

\subsection{Data analysis}

To exclude highly correlated $(r>0.8)$ variables, we assessed relationships between pairs of variables by nonparametric Spearman's correlation coefficient. None of the variables was highly correlated with another, so all the variables (with exception of cover of sand and gravel substrate in natural ponds because those variables had zero values) were used for further analysis.

Environmental variables were tested for differences between artificial and natural ponds by a nonparametric
Mann-Whitney $U$ test due to prevailing non-normality in the dataset.

Than, variables were transformed for improving homoscedasticity where necessary. Log transformation was used for cover of fine and sand substrate, and altitude; for all types of $\mathrm{LU}$ and content of $\mathrm{NH}_{4}{ }^{+}, \mathrm{NO}_{3}{ }^{-}, \mathrm{NO}_{2}{ }^{-}$and $\mathrm{PO}_{4}{ }^{3-}$, cube root transformation was used.

The species occurrence data were split into four presence/ absence matrices. The first matrix was composed of helophyte species, the second of hydrophytes (true aquatic species), the third of both species categories and the fourth represented red list species. Classification of helophyte and hydrophyte species groups was based on previous studies (Alahuhta et al., 2012; Landucci et al., 2015; Kolada, 2016); 15 recorded non-wetland or non-aquatic species were excluded from the dataset (Appendix A). Next, we conducted analyses for comparison of diversity between artificial and natural ponds. Local (alpha, $\alpha$ ) diversity was defined as raw species number within the sampling area in individual ponds. For testing possible differences in alpha diversity between artificial and natural ponds, we ran a one-way ANOVA with origin of pond as a fixed effect. Firstly, we conducted the Bartlett test for checking the homogeneity of variances. Due to non-normality of the dataset, a permutational ANOVA was applied. Among-site (beta, $\beta$ ) similarity was described by Jaccard's index, and a test of multivariate homogeneity of variances by the function betadisper (Oksanen et al., 2016) was run for testing possible differences between pond types. Because of uneven samples of pond types we randomly selected 26 localities from subset of artificial ponds and repeated testing ten times (every time with new randomly selected subset). Regional (gamma, $\gamma$ ) diversity was the total richness of all sites within one pond type. We ran a randomization test based on differences between total 
K. Bubíková and R. Hrivnák: Knowl. Manag. Aquat. Ecosyst. 2018, 419, 8

Table 3. Final selected significant variables for GLM explaining local diversity in ponds with explained percent deviation $(D \%)$. Signs “+” and “_" indicate positive or negative effect on $\alpha$-diversity. Variable characteristics and values are in Table 1.

\begin{tabular}{lccc}
\hline Pond type & Species group & Variables & D\% \\
\hline \multirow{4}{*}{ Artificial ponds } & All species & LU - Field (+) & 21.3 \\
& Helophytes & LU - Field (+), NO2 content (-) & 37.2 \\
& Hydrophytes & Water turbidity (-) & 12.5 \\
& Red list species & Altitude (+) & 12.7 \\
\hline \multirow{4}{*}{ Natural ponds } & All species & Shading (-), substrate - fine (+), connectivity (-) & 40.6 \\
& Helophytes & Shading (-), substrate - fine (+), bank - gradual (+) & 43.1 \\
& Hydrophytes & Shading (-) & 15 \\
& Red list species & Water turbidity (-) & 14.4 \\
\hline
\end{tabular}

richness of pond types for testing possible differences between pond types using the c2cv function (Rossi, 2011).

Species richness (defined as raw count of species within a sampling area in an individual pond) was modelled separately for each species group and type of pond (altogether 8 models) using generalised linear models (GLM) with an assumed Poisson distribution and log link function (McCullagh and Nelder, 1989) and with backward stepwise selection. Firstly, the p-value was set to $<0.15$ for including potentially meaningful variables, and then for final models we assessed the $p$-value at $<0.05$.

All analyses were performed in R software ( $\mathrm{R}$ Core Team, 2016), using the libraries vegan (Oksanen et al., 2016), lmPerm (Wheeler and Torchiano, 2016) and Rich (Rossi, 2011). Results were considered as significant at $\alpha=95 \%$.

\section{Results}

\subsection{Environmental characteristics of ponds}

The artificial and natural ponds significantly differed in 8 environmental variables. Artificial ponds occurred in manmodified areas and that fact was reflected by higher share of the agricultural field and artificial type of landscape in the vicinity of ponds and lower shading by bank vegetation. Sand and gravel substrates did not occur in any of the natural ponds and in contrast, the cover of fine substrate was higher in natural ponds. Water $\mathrm{pH}$ and content of $\mathrm{NH}_{4}{ }^{+}$differed between pond types with higher concentrations of $\mathrm{NH}_{4}{ }^{+}$in natural and higher $\mathrm{pH}$ in artificial ponds. Water was significantly deeper in artificial ponds which were mainly permanent, while natural ponds were shallower and with more fluctuating water level (Tab. 1).

\subsection{Species richness and diversity of ponds}

Altogether, 60 species were found (Tab. A.1). The most frequent species were Myriophyllum spicatum (29\% of ponds), Ceratophyllum demersum (20\%), Lemna minor (17\%) and Phragmites australis (12\%); 19 species occurred at single site only. The average number of species per pond was 3.9 with a range from 0 to 20 species. From a total number of 16 red-list species, 13 were found in natural and 11 in artificial ponds.

Mean $\alpha$-diversity in case of all species group was higher in natural ponds than in artificial ponds. Natural ponds were richer than artificial ponds in number of all species, helophytes and red-list species (Tab. 2).

Permutational ANOVA yielded significant differences only for the helophytes, while hydrophytes, red-list species and overall species number were not significantly different between artificial and natural ponds (Tab. 2).

The highest mean $\beta$-similarity (0.15) was observed in hydrophytes in artificial ponds, while red list species in natural ponds showed the lowest (0.03) $\beta$-similarity. A test of multidimensional dispersion showed significant differences for all species, helophytes and red-list species groups; $\beta$-similarity of hydrophytes also differed but from 10 randomly selected subsets only six showed significant difference and four not (Tab. 2).

Regional diversity was higher for all species, helophytes and red-list species in natural ponds, while $\gamma$-diversity of hydrophytes was the same for both pond types. Randomization tests showed significant differences in all species and helophytes, $\gamma$-diversity of hydrophytes was the same for both pond types and for red-list species was not significantly different between artificial and natural ponds (Tab. 2).

\subsection{Effect of environmental variables on species richness}

Final models obtained from GLM (Tab. 3) totally differed in significant predictors of $\alpha$-diversity between pond types. In artificial ponds, only the model for the helophytes consisted of two significant variables (nitrite content with negative and LU fields with positive influence) and explained the most deviation (37.2\%); for other species groups, only one predictor was significant and the percentage of explained deviation was lower. For natural ponds, models for all species and helophytes contained three significant predictors and both models explained about $40 \%$ of the deviation; for hydrophytes and red-list species, only one variable was significant (shading and water turbidity for hydrophytes and red-list species, respectively) and models showed about $15 \%$ of explained deviation.

\section{Discussion}

\subsection{Species diversity}

Comparing species richness of ponds in Europe, we can state that ponds in Slovakia are species poorer than adequate waterbodies from neighbouring countries such as Poland or 
Hungary (Bosiacka and Pieńkowski, 2012; Szoszkiewicz et al., 2014; Lukács et al., 2015) and the rest of Europe (Oertli et al., 2002; Gledhill et al., 2008; Chappuis et al., 2012). Generally, the eastern part of Europe is known for lower macrophyte species richness (Chappuis et al., 2012) and higher species richness in Hungary or Poland could be influenced by inclusion of all observed species, not only true aquatic plants or helophytes. However, a potential weakness of such comparison is in fact that cited surveys were focused mainly on ponds and lakes with area more than two hectares; macrophyte richness increases with area (Jones et al., 2003) so effect of pond area on species richness should be taken account. Also presence of alien aquatic species and species with Atlantic or Boreal distribution can play important role. Number of aquatic alien species in Slovakia is much lower than in Hungary (Medvecká et al., 2012; Lukács et al., 2016). Atlantic and boreal aquatic plant species, which are relatively frequent in Poland, are absent in Western Carpathian region in Slovakia (cf. Otahel'ová in Valachovič, 1995; Matuszkiewicz, 2008).

We studied whether artificial ponds differ from natural ponds in the case of all three types of biodiversity (local, among-site, regional) and thus whether they are an appropriate substitution for maintaining macrophyte diversity in consideration of the declining quantity and quality of natural ponds.

Macrophyte local $(\alpha)$ diversity was higher in natural ponds for all species groups, but a significant difference was obtained for the helophytes only. Thus, artificial ponds are equal in comparison with natural ponds in the case of $\alpha$-diversity. Based on our results, significantly lower counts of helophytes were caused by the common absence of gradual banks and shallow littoral zone in artificial waterbodies mainly in case of gravel or mud pits. Moreover, relatively shallow water and fluctuating water regime in natural ponds enhances the colonisation by helophytes in littoral zone (Nicolet et al., 2004; Rhazi et al., 2012; Lukács et al., 2013). In addition to mentioned characteristics, higher variance of water reaction and higher ammonia content in case of natural ponds can play important role for presence of broader groups of macrophytes including helophytes ( $c f$. Lacoul and Freedman, 2006; Kolada, 2016). From conservation point of view, finding that local diversity of endangered species did not significantly differ between artificial and natural ponds is positive. Lower counts of helophytes in artificial ponds had no effect in the case of endangered species because only Butomus umbellatus belong to both helophytes and red list species groups. Although a prevailing kind of consensus resulting from previous surveys assesses artificial lentic waterbodies as comparable to the natural ones (Wezel et al., 2014), no direct comparison supported by statistical tests exists. Studies were focused on comparative diversity of ponds with other aquatic ecosystems like streams, rivers or ditches with a conclusion of high $\alpha$-diversity and counts of endangered species in ponds; however, authors included both natural and artificial standing waters into the dataset (Williams et al., 2004; Biggs et al., 2005; Biggs et al., 2007; Davies et al., 2008a, Davies et al., 2008b). Other authors (e.g. Hrivnák et al., 2014) found that waterbodies with artificial origin had higher species richness than those with natural origin. However, artificial waterbodies included mainly habitats with standing or slow running water (ponds, canals), while natural origin combined habitats with running (streams, rivers) and standing (river oxbows) water. Moreover, streams and rivers belong to relatively species poor aquatic ecosystems in Central Europe (Svitok et al., 2016).

Macrophyte among-site $(\beta)$ similarity showed slightly higher Jaccard's index in artificial ponds with significantly different values for all studied species groups. Previously discussed heavy modifications narrow amount of species with ability to grow in artificial ponds which resulted in more unified macrophyte communities there. Thus, we can assume that even though artificial ponds seems to be more diverse in habitat conditions resulting from their varied origins, local environment is relatively unified across broader area. In spite of this statement, artificial ponds can be important secondary aquatic habitats for the survival of macrophytes. Due to good spreading ability of aquatic plant species (Figuerola et al., 2005; Neff and Baldwin, 2005), artificial ponds could serve as reservoirs of diaspores for potential further colonisation of distant aquatic habitats.

Natural ponds also showed higher regional $(\gamma)$ diversity which significantly differed from artificial ponds in all species and helophytes. Higher total species numbers were found despite the relatively lower number of localities for natural ponds. This fact indirectly supports the previously stated importance of ponds for maintaining aquatic biodiversity (Oertli et al., 2002; Biggs et al., 2005; Céréghino et al., 2014) because a relatively low number of localities of natural ponds harboured comparable species counts found during previous surveys in Slovakia with more sampling sites (Otahel'ová et al., 2007; Svitok et al., 2016). Similarly to $\alpha$-diversity, artificial ponds held markedly lower helophytes $\gamma$-diversity which influenced and caused a significant difference in species pool of all species. Surprisingly, the number of hydrophytes was the same for both pond types ( 27 species) and numbers of red-list species (13 and 11 for natural and artificial ponds, respectively) were not significantly different. This leads to the conclusion that the main difference between artificial and natural ponds is the occurrence of helophytes which are limited in artificial waterbodies mainly by unsuitable bank morphology, greater depth and less frequent season water fluctuation comparing to natural ponds.

\subsection{Alpha diversity and environmental variables}

The positive effect of fields and no negative influence by urbanised areas in the vicinity of ponds on $\alpha$ diversity was the interesting result obtained in GLM. Heavily modified surrounding landscape is undoubtedly considered as a factor causing diversity loss in waterbodies, due to increasing eutrophication as a consequence of fertiliser and sewage runoff (Carpenter et al., 1998; Scheffer and Carpenter, 2003; Akasaka et al., 2010). Moreover, the negative effect of nitrite content on helophyte diversity was observed. Thus, we assume that the positive effect of fields on macrophyte diversity in artificial ponds is mainly in suppression of shading or providing organic litter (Barko and Smart, 1983; Lacoul and Freedman, 2006). Whilst shading was a negative factor affecting diversity of all species, helophytes and hydrophytes in natural ponds. Another remarkable finding is the positive effect of altitude on diversity of red-list species in artificial ponds because diversity decrease as a consequence of higher elevation is well known 
(Hinden et al., 2005; Lacoul and Freedman, 2006). Altitude range was probably insufficient to show those negatives and presumably the hidden effect of strong human utilisation in lower altitudes across factors such as presence of fields in lowlands and related nutrient runoff that leads to a positive effect of altitude on diversity in artificial ponds. As discussed above, the importance of substrate in lentic waterbodies is mainly in providing nutrients rather than for assisting rooting. The occurrence of fine substrate increases species diversity in both lotic and lentic waterbodies (Svitok et al., 2016). Here, we found a positive influence on diversity of all species and in combination with gradual banks also for helophytes in natural ponds. Generally, non-modified banks in natural habitats offer suitable conditions such as shallow water or fine substrate for proper development of helophyte communities (Zelnik et al., 2012). From the set of water characteristics, only turbidity had a significant negative impact on diversity of helophytes and redlist species in artificial and natural ponds, respectively. Turbidity is associated with light limitations which negatively affects macrophyte growth (Akasaka et al., 2010, Kolada, 2016) including germination and growing of juvenile helophytes. Another factor related to turbidity is higher nutrient content (Lacoul and Freedman, 2006), which probably contributed to the negative effect of turbidity on red-list species. Proximity or connection with other waterbodies positively affects species composition via dispersal of individuals between habitats (Lacoul and Freedman, 2006; Akasaka and Takamura, 2012; Bosiacka and Pieńkowski, 2012; Waldon, 2012) which was also confirmed by positive effect of connectivity on diversity of all species in natural ponds where the higher level of isolation is the more negative effect on diversity.

\section{Conclusions}

Our study critically compared species diversity of aquatic macrophytes between artificial and natural ponds on environmental background in two bioregions of Central Europe. The main conclusion to be drawn from presented results is that artificial ponds are rather comparable to natural ones in the case of macrophyte species richness and diversity, and may serve as suitable secondary habitats for maintenance of aquatic plants. Such information is important due to the rapid decline of natural waterbodies in the cultural landscape during recent decades. Undoubtedly, artificial ponds could never absolutely substitute the natural ones due to limitations in development of new microhabitat or ecotones based on artificial origin; actually, this has reflected in a lower number of helophytes and resulting differences in all types of diversity for this species group. On the other hand, hydrophytes and red-list species showed the same or similar richness and with exception of $\beta$-similarity those groups did not differ between both pond types, which accurately highlights the role of anthropogenic waterbodies for maintaining macrophyte diversity. Furthermore, similarity was achieved despite the fact that $\mathrm{pH}$ values and depth, which are commonly important drivers of species composition in freshwater ecosystems (Lacoul and Freedman, 2006), significantly differed between pond types. Overall, from the set of 24 environmental factors according to GLM, only eight of them influenced $\alpha$-diversity in species groups.
This leads to the conclusion that even though artificial and natural ponds vary in environmental conditions and discrepant factors influence differently species groups, differences in diversity at all three levels (local, among-site and regional) are caused mainly by occurrence of different counts of helophyte species. Thus, we can confirm the importance of artificial standing waters for maintaining aquatic plant diversity at least in part of the Carpathian and Pannonian bioregions.

Acknowledgements. We would like to thank Judita Kochjarová and Barbara Immerová for their assistance during the field work, Peter Pal'ove-Balang for laboratory analyses, Michal Hájek, Milan Novikmec and three anonymous reviewers for useful comments to manuscript. This study was supported by the VEGA Grant Agency under contract No. 2/0030/17.

\section{References}

Akasaka M, Takamura N. 2012. Hydrologic connection between ponds positively affects macrophyte $\alpha$ and $\gamma$ diversity but negatively affects $\beta$ diversity. Ecology 93: 967-973.

Akasaka M, Takamura N, Mitsuhashi H, Kadono Y. 2010. Effects of land use on aquatic macrophyte diversity and water quality of ponds. Freshw Biol 55: 909-922.

Alahuhta J, Kanninen A, Vuori K-M. 2012. Response of macrophyte communities and status metrics to natural gradients and land use in boreal lakes. Aquat Bot 103: 106-114.

Barko JW, Smart RM. 1983. Effects of organic-matter additions to sediment on the growth of aquatic plants. J Ecol 71: 161-175.

Biggs J, Williams P, Whitfield M, Nicolet P, Weatherby A. 2005. 15 years of pond assessment in Britain: results and lessons learned from the work of pond conservation. Aquat Conserv 15: 693-714.

Biggs J, Williams P, Whitfield M, Nicolet P, Brown C, Hollis J, Arnold D, Pepper T. 2007. The freshwater biota of British agricultural landscapes and their sensitivity to pesticides. Agric Ecosyst Environ 122: 137-148.

Biggs J, von Fumetti S, Kelly-Quinn M. 2017. The importance of small waterbodies for biodiversity and ecosystem services: implications for policy makers. Hydrobiologia 793: 3-39.

Bosiacka B, Pieńkowski P. 2012. Do biogeographic parameters matter? Plant species richness and distribution of macrophytes in relation to area and isolation of ponds in NW Polish agricultural landscape. Hydrobiologia 689: 79-90.

Broyer J, Curtet L. 2012. Biodiversity and fish farming intensification in French fishpond systems. Hydrobiologia 694: 205-218.

Carpenter SR, Caraco NF, Correll DL, Howarth RW, Sharpley AN, Smith VH. 1998. Nonpoint pollution of surface waters with phosphorus and nitrogen. Ecol Appl 8: 559-568.

Céréghino R, Boix D, Cauchie HM, Martens K, Oertli B. 2014. The ecological role of ponds in a changing world. Hydrobiologia 723: 1-6.

Chappuis E, Ballesteros E, Gacia E. 2012. Distribution and richness of aquatic plants across Europe and Mediterranean countries: patterns, environmental driving factors and comparison with total plant richness. J Veg Sci 23: 985-997.

Chester ET, Robson BJ. 2013. Anthropogenic refuges for freshwater biodiversity: their ecological characteristics and management. Biol Conserv 166: 64-75.

Crivelli AJ. 1983. The destruction of aquatic vegetation by carp. Hydrobiologia 106: 37-41.

Davies BR, Biggs J, Williams PJ, Whitfield M, Nicolet P, Sear D, Bray S, Maund S. 2008a. Comparative biodiversity of aquatic habitats in the European agricultural landscapes. Agric Ecosyst Environ 125: 1-8. 
Davies BR, Biggs J, Williams PJ, Lee JT, Thompson S. 2008b. A comparison of the catchment sizes of rivers, streams, ponds, ditches and lakes: implications for protecting aquatic biodiversity in an agricultural landscape. Hydrobiologia 597: 7-17.

Declerck S, De Bie T, Ercken D, Hampel H, Schrijvers S, Van Wichelen J, Gillard V, Mandiki R, Losson B, Bauwens D, Keijers S, Vyverman W, Goddeeris B, De Meester L, Brendonck L, Martens K. 2006. Ecological characteristics of small farmland ponds: associations with land use practices at multiple spatial scales. Biol Conserv 131: 523-532.

Della Bella V, Bazzanti M, Dowgiallo MG, Iberite M. 2008. Macrophyte diversity and physico-chemical characteristics of Tyrrhenian coast ponds in central Italy: implications for conservation. Hydrobiologia 597: 85-95.

Dodds W, Whiles M. 2010. Freshwater ecology, 2nd ed. Cambridge, USA: Elsevier Academic Press, 813 p.

Downing JA, Prairie YT, Cole JJ, Duarte CM, Tranvik LJ, Striegl RG, McDowell WH, Kortelainen P, Caraco NF, Melack JM, Middelburg JJ. 2006. The global abundance and size distribution of lakes, ponds and impoundments. Limnol Oceanogr 51: 2388-2397.

Dudgeon D, Arthington AH, Gessner MO, Kawabata ZI, Knowler DJ, Léveque C, Naiman RJ, Prieur-Richard AH, Soto D, Stiassny MLJ, Sullivan CA. 2006. Freshwater biodiversity: importance, threats, status and conservation challenges. Biol Rev 81: 163-182.

Edvardsen A, Økland RH. 2006. Variation in plant species composition in and adjacent to 64 ponds in SE Norwegian agricultural landscapes. Aquat Bot 85: 92-102.

Eliáš P Jr., Dítě D, Kliment J, Hrivnák R, Feráková V. 2015. Red list of ferns and flowering plants of Slovakia, 5th ed. (October 2014). Biologia 70: 218-228.

European Commission, 2014, Environment 2000: Natura 2000Pannonian biogeographical region, http://ec.europa.eu/environ ment/nature/natura2000/sites_hab/biogeog_regions/index_en. htm\#pannonian.

Figuerola J, Santamaria L, Green AJ, Luque I, Alvarez R, Charalambidou I. 2005. Endozoochorous dispersal of aquatic plants: does seed gut passage affect plants performance? Am J Bot 92: 696-699.

Gee JHR, Smith BD, Lee KM, Griffiths SW. 1997. The ecological basis of freshwater pond management for biodiversity. Aquat Conserv 7: 91-104.

Gledhill DG, James P, Davies DH. 2008. Pond density as a determinant of aquatic species richness in an urban landscape. Landsc Ecol 23: 1219-1230.

Hindák F, Hindáková A. 2001. Červený zoznam siníc/cyanobaktérií a rias Slovenska. 2. Verzia, (December 2001). Ochr Prir 20 (suppl): 14-22.

Hinden H, Oertli B, Menetrey N, Sager L, Lachavanne JB. 2005. Alpine pond biodiversity: what are the related environmental variables? Aquat Conserv 15: 613-624.

Hrivnák R, Otahel'ová H, Kochjarová J, Pal'ove-Balang P. 2013. Effect of environmental conditions on species composition of macrophytes in two distinct biogeogrphical regions of Central Europe. Knowl Manag Aquat Ecosyst 411: 09.

Hrivnák R, Kochjarová J, Otahel’ová H, Pal'ove-Balang P, Slezák M, Slezák P. 2014. Environmental drivers of macrophyte species richness in artificial and natural aquatic water bodies comparative approach from two central European regions. Ann Limnol-Int J Limnol 50: 269-278.

Janauer GA. Methods. In: Janauer GA, Hale P, Sweeting R (eds.) Macrophyte inventory of the river Danube: a pilot study. Large Rivers: Arch Hydrobiol, 2003, pp. 9-16.
Jones JI, Li W, Maberly SC. 2003. Area, altitude and aquatic plant diversity. Ecography 26: 411-420.

Kadoya T, Suda S, Tsubaki Y, Washitani I. 2008. The sensitivity of dragonflies to landscape structure differs between life-history groups. Landsc Ecol 23: 461-467.

Kadoya T, Akasaka M, Aoki T, Takamura N. 2011. A proposal of framework to obtain an integrated biodiversity indicator for agricultural ponds incorporating the simultaneous effects of multiple pressures. Ecol Indic 11: 1396-1402.

Kolada A. 2016. The use of helophytes in assessing eutrophication of temperate lowland lakes: added value? Aquat Bot 129: $44-54$.

Lacoul P, Freedman B. 2006. Environmental influences on aquatic plants in freshwater ecosystems. Environ Rev 14: 89-136.

Landucci F, Tichý L, Šumberová K, Chytrý M. 2015. Formalized classification of species-poor vegetation: a proposal of a consistent protocol for aquatic vegetation. J Veg Sci 26: 791-803.

Linton S, Goulder R. 2000. Botanical conservation value related to origin and management of ponds. Aquat Conserv 10: 77-91.

Lukács BA, Sramkó G, Molnár A. 2013. Plant diversity and conservation value of continental temporary pools. Biol Conserv 158: 393-400.

Lukács BA, Tóthméréz B, Borics G, Várbíró G, Juhász P, Kiss B, Müller Z, Tóth LG, Erős T. 2015. Macrophyte diversity of lakes in the Pannnon Ecoregion (Hungary). Limnologica 53: $74-83$.

Lukács, BA, Mesterházy A, Vidéki R, Király G. 2016. Alien aquatic vascular plants in Hungary (Pannonian ecoregion): historical aspects, data set and trends. Plant Biosyst 150: 388-395.

Marhold K, Hindák F. 1998. Checklist of non-vascular and vascular plants of Slovakia, Bratislava: Veda, $688 \mathrm{p}$.

Matuszkiewicz W. 2008. Przewodnik do oznaczania zbiorovisk ros linnych Polski [Guide of plant communities in Poland], Warszawa: Wydawnictwo Naukowe PWN, 540 p.

McCullagh P, Nelder J.A. 1989. Generalized Linear Models, 2nd ed. London: Chapman \& Hall, $532 \mathrm{p}$.

Medvecká J, Kliment J, Májeková J, Halada L, Zaliberová M, Gojdičová E, Feráková V, Jarolímek I. 2012. Inventory of alien species of Slovakia. Preslia 84: 257-309.

Millennium Ecosystem Assessment, 2005. Ecosystems and human well-being - synthesis, Washington DC: Island Press.

Neff KP, Baldwin AH. 2005. Seed dispersal into wetlands: techniques and results for restored tidal freshwater marsh. Wetlands 25: $392-$ 404.

Nicolet P, Biggs J, Fox G, Hodson MJ, Reynolds C, Whitfield M, Williams P. 2004. The wetland plant and macroinvertebrate assemblages of temporary ponds in England and Wales. Biol Conserv 120: 261-278.

Oertli B, Joye DA, Castella E, Juge R, Cambin D, Lachavanne J.B. 2002. Does size matter? The relationship between pond area and biodiversity. Biol Conserv 104: 59-70.

Oksanen J, Blanchet FG, Kindt R, Legendre P, Minchin PR, O'Hara RB, Simpson GL, Solymos P, Stevens MHH, Wagner H. 2016. Vegan: Community Ecology Package. R package version 2.3-3, http://CRAN.R-project.org/package=vegan.

Otahel'ová H, Valachovič M, Hrivnák R. 2007. The impact of environmental factors on the distribution patter of aquatic plants along the Danube River corridor (Slovakia). Limnologica 37: 290302.

R Core Team. 2016. R: a language and environment for statistical computing, Vienna, Austria: R Foundation for Statistical Computing, https://www.R-project.org/. 
K. Bubíková and R. Hrivnák: Knowl. Manag. Aquat. Ecosyst. 2018, 419, 8

Rhazi L, Grillas P, Saber ER, Rhazi M, Brendonck L, Waterkeyn A. 2012. Vegetation of Mediterranean temporary pools: a fading jewel? Hydrobiologia 689: 23-36.

Rossi J-P. 2011. Rich: an R package to analyse species richness. Diversity 3: 112-120.

Sayer C, Andrews K, Shilland E, Edmonds N, Edmonds-Brown R, Patmore I, Emson D, Axmacher J. 2012. The role of pond management for biodiversity conservation in an agricultural landscape. Aquat Conserv 22: 626-638.

Scheffer M, Carpenter SR. 2003. Catastrophic regime shifts in ecosystems: linking theory to observation. Trends Ecol Evol 18: 648-656.

Spałek K. 2006. Threatened plant communities as an indicator of fishponds value: an example from Silesia (SW Poland). In: Gafta D, Akeroyd J, (eds.) Nature conservation. Concepts and practice. Heidelberg: Springer Verlag, 195-198.

Šumberová K, Ducháček M, Lososová Z. 2012. Life-history traits controlling the survival of Tillaea aquatica: a threatened wetland plant species in intensively managed fishpond landscapes of the Czech Republic. Hydrobiologia 689: 91-110.

Svitok M, Hrivnák R, Kochjarová J, Otahel'ová H, Pal'ove-Balang P. 2016. Environmental thresholds and predictors of macrophyte species richness in aquatic habitats in central Europe. Folia Geobot 51: 227-238.
Szoszkiewicz K, Ciecierska H, Kolada A, Schneider SC, Szwabińska M, Ruszczyńska J. 2014. Parameters structuring macrophyte communities in rivers and lakes - results from a case study in North-Central Poland. Knowl Manag Aquat Ecosyst 415: 08.

Toivonen H, Huttunen P. 1995. Aquatic macrophytes and ecological gradients in 57 small lakes in southern Finland. Aquat Bot 51: 197221.

Valachovič M. (ed.) 1995. Rastlinné spoločenstvá Slovenska 1. Pionierska vegetácia mokradí [Plant communities of Slovakia 1. Pioneer vegetation]. Bratislava: Veda $184 \mathrm{p}$.

Waldon B. 2012. The conservation of small water reservoirs in the Krajeńskie Lakeland (North-West Poland). Limnologica 42: 320-327.

Wezel A, Oertli B, Rosset V, Arthaoud F, Leroy B, Smith R, Angélibert S, Bornette G, Vallod D, Robin J. 2014. Biodiversity patterns of nutrient-rich fish ponds and implications for conservation. Limnology 15: 213-223.

Wheeler B, Torchiano M. 2016. lmPerm: Permutation tests for linear models. $\mathrm{R}$ package version 2.1.0.

Williams P, Whitfield M, Biggs J, Bray S, Fox G, Nicolet P, Sear D. 2004. Comparative diversity of rivers, streams, ditches and ponds in an agricultural landscape in Southern England. Biol Conserv 115: 329-341.

Zelnik I, Potisek M, Gaberščik A. 2012. Environmental conditions and macrophytes of Karst ponds. Pol J Environ Stud 21: 1911-1920.

Cite this article as: Bubíková K, Hrivnák R. 2018. Artificial ponds in Central Europe do not fall behind the natural ponds in terms of macrophyte diversity. Knowl. Manag. Aquat. Ecosyst., 419, 8. 


\section{Appendices}

\section{Appendix A List of observed species; asterisk indicates red-list species}

Table A.1. The list of observed species.

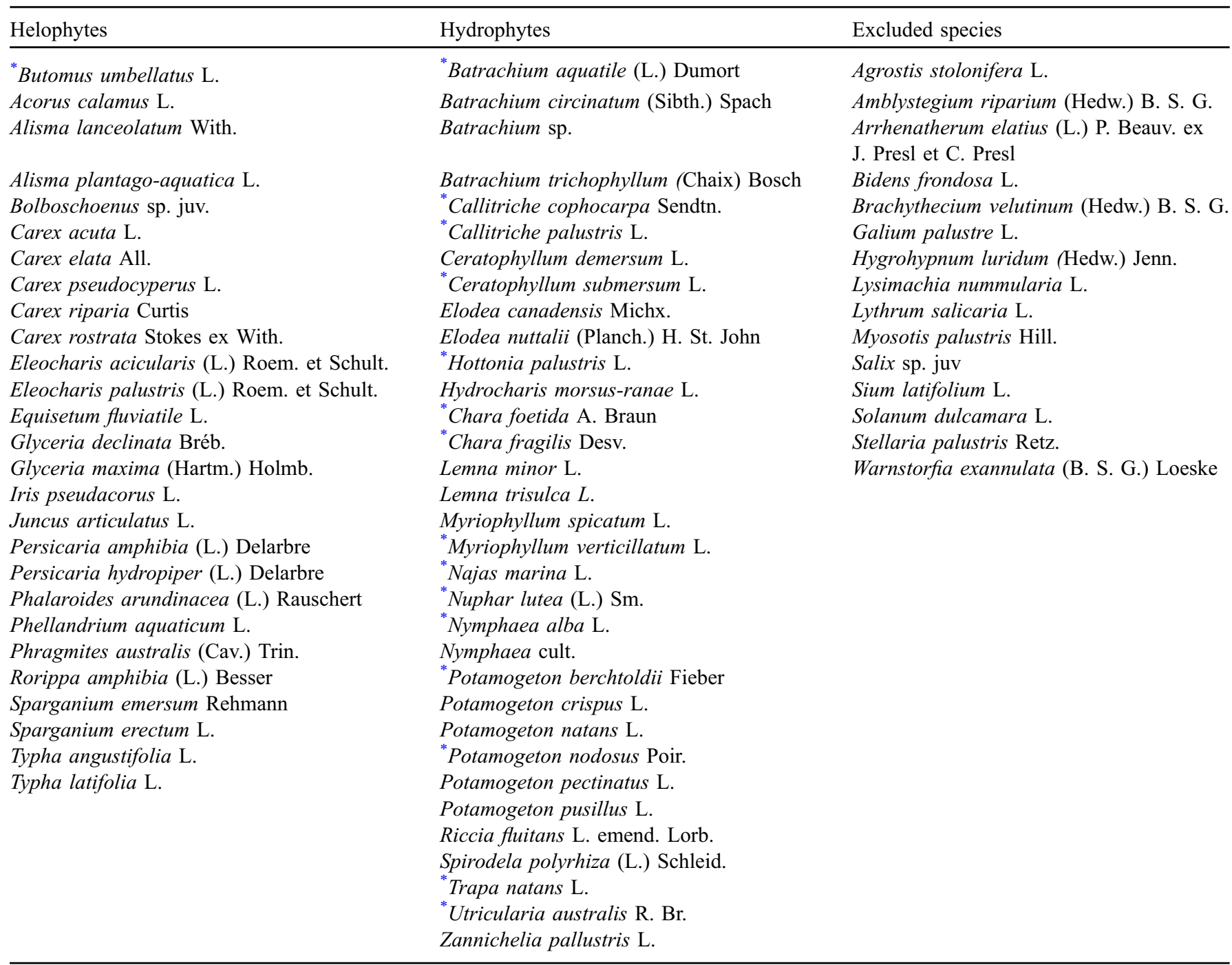

\footnotetext{
${ }^{*}$ Red-list species.
} 